ISSN 0258-7122

Bangladesh J. Agril. Res. 37(1): 67-75, March 2012

\title{
PRESERVATION OF JACKFRUIT (Artocarpus heterophyllus) BY OSMOTIC DEHYDRATION
}

\author{
MD. MiZANUR RAHMAN ${ }^{1}$, MD. MIARUDDIN ${ }^{2}$, M.G. FERDOUS CHOWDHURY ${ }^{3}$ \\ MD. HAFIZUL HAQUE KHAN ${ }^{4}$ AND MD. MUZAHID-E-RAHMAN ${ }^{5}$
}

\begin{abstract}
Preservation of jackfruit (Artocarpus heterophyllus) by osmotic dehydration method has been standardized. Four treatments of sugar concentration viz. $35^{\circ}$, $40^{\circ}, 45^{\circ}$, and $50^{\circ}$ Brix were used for osmotic dehydration. After osmosis of the jackfruit slices in the sugar solutions these were laid on the cabinet drier for dehydration. After osmotic dehydration, the products were packed in high density polyethylene bags and stored in ambient temperature for a period of 8 months. The physico-chemical properties and the microbiological changes of the products were evaluated and a taste panel evaluated the organoleptic quality of the products during the storage period. Minimum microbial count was recorded for osmosis in $50^{\circ}$ Brix sugar solution followed by $45^{\circ}$ Brix sugar solution. The retention of vitamin $A$ ( $($ - carotene), vitamin $C$, total acid and total sugar was also better for osmosis in $45^{\circ}$ Brix sugar solution followed by $50^{\circ}$ Brix sugar solution. The product of $45^{\mathrm{O}}$ Brix solution when stored 8 months at room temperature secured highest score in organoleptic evaluation and was ranked “ like moderately" followed by the product of $50^{\circ}$ Brix solution. Considering the overall acceptance of sensory evaluations, retention of nutritional quality and quantity of sugar needed, the osmotic dehydrated jackfruit prepared by $45^{\circ}$ Brix sugar solution could be selected for commercial processing.
\end{abstract}

Keywords: jackfruit preservation, osmotic dehydration.

\section{Introduction}

The jackfruit (Artocarpus heterophyllus) has been named as the national fruit of Bangladesh. It is one of the largest fruits to grow on trees in the world, and a jackfruit tree can live and bear fruit for approximately a hundred years if taken care of correctly (Anon., 2011).

The climate in Bangladesh is perfect for the cultivation of jackfruit trees and in addition to its nutritional value; the Jackfruit is an inexpensive fruit and can be bought or grown in the poorest communities. The size of the fruit also adds to its value, but is unfortunately known to be somewhat of an acquired taste to some people. Jackfruit in Bangladesh is viewed as delicious, sweet, tasty, and juicy.

${ }^{1}$ Scientific Officer, Postharvest Technology Division, Bangladesh Agricultural Research Institute (BARI), Gazipur, ${ }^{2}$ Principal Scientific Officer, Postharvest Technology Division, BARI, Gazipur, ${ }^{3}$ Principal Scientific Officer, Postharvest Technology Division, BARI, Gazipur, ${ }^{4}$ Senior Scientific Officer, Postharvest Technology Division, BARI, Gazipur, ${ }^{5}$ Scientific Officer, Plant Pathology Division, BARI, Gazipur, Bangladesh. 
Many people use jackfruit in unripe stage for their curries and other cuisine. It could be made into a variety of different products, such as canned fruit, dried fruit and pulp. The total production of jackfruit in Bangladesh is about 925.97 thousand metric tons from 24.654 thousand acres of land (BBS, 2007) and they are characterized by their perishability and seasonality. Postharvest losses of this fruit are very high due to lack of storage facilities and mishandling operations. Bangladesh produces over 10.81 million tons of fruits and vegetables (BBS, 2007). There is estimation that only $0.5 \%$ of the horticultural produces are processed (Tongsiri and Alam, 2004). Most of the fruits and vegetables are seasonal. During the peak season they appear in the market and form glut to abundant supply at a time and the price comes down causing economic loss to the growers. All these factors discourage the growers from producing more. So reduction of postharvest losses and increases of their shelf life has become an urgent need in order to extend their availability round the year. Processing and preservation can play a vital role in reducing postharvest losses of fruits and vegetable and make them available during off-season.

Osmotic dehydration, a method of preservation has the advantage of being very easy to perform for home and small scale processing. Now a day, there is a huge demand for dried fruits both in domestic as well as in foreign markets. Osmotic dehydration if optimized will reduce losses, improve availability and allow diversification of processed product. It also will add value to the most abundant fruit of Bangladesh.

\section{Materials and Method}

The jackfruits were washed, peeled, removed the seed from bulb and sliced length wise. There were four treatments comprising of four concentration of sugar syrup as follows:

$$
\begin{aligned}
& \mathrm{T}_{1}=35^{\circ} \text { Brix sugar syrup } \\
& \mathrm{T}_{2}=40^{\circ} \text { Brix sugar syrup } \\
& \mathrm{T}_{3}=45^{\circ} \text { Brix sugar syrup } \\
& \mathrm{T}_{4}=50^{\circ} \text { Brix sugar syrup }
\end{aligned}
$$

So, slices of the jackfruits were divided into four groups and dipped into the sugar syrup concentrations_and kept 30 minutes for soaking. Then, the slices were heated at $80^{\circ} \mathrm{C}$ for 45 minutes. Finally, the slices were kept for $3 \mathrm{hrs}$ again for soaking and $2000 \mathrm{ppm}$ potassium metabisulphite (KMS) were added according to FPO specification (Ranganna, 2007). The slices were transferred to drying trays and dehydrated at $50^{\circ} \mathrm{C}$ for $24 \mathrm{hrs}, 55^{\circ} \mathrm{C}$ for $24 \mathrm{hrs}$ and finally $60^{\circ} \mathrm{C}$ for $8 \mathrm{hrs}$. The time and temperature of drying of the jackfruit slices in the mechanical dryer was fixed up after several trials. After dehydration, the slices were packed in high density polyethylene packet and stored at ambient 
temperature. The stored samples were analyzed at monthly intervals for moisture, acidity, total and reducing sugars as per method described by Ranganna (2007), ß-carotnene by NIN procedure and ascorbic acid by the procedure described by Mahadevan and Sridhar (1982). Microbial load (bacteria, fungi and yeast) was estimated in the stored osmotic dehydrated jackfruit by the method described by Istavan Kiss (1984) at monthly intervals by adopting pour plate method using serial dilution technique.

\section{Sensory evaluation}

Stored osmotic dehydrated jackfruits were examined by a panel of 10 judges comprising of scientific staff for their color, flavor/taste, texture/stickiness and overall acceptance. Hedonic scale was used to make the different parameters. In this scale 'like extremely", is given the highest score of 9 and 'dislike extremely' is given the lowest score 1. Others are given intermediate scores. The data were analyzed for ANOVA in completely randomized design (CRD) under computerized statistical methods of M-stat and Duncan's Multiple Range Test (DMRT) was used to compare the means.

\section{Results and Discussion}

The prepared osmotic dehydrated jackfruit is not suitable for consumption immediately after drying due to its stickiness and hardness. The stickiness of the product that is assumed to be the critical sensory attributes remains high at the beginning of preparation. It was observed that storage time is essential for seasoning for the improvement of stickiness and hardness of the osmotic dehydrated jackfruit slices.

The changes in various physico-chemical parameters of the dehydrated jackfruits stored in ambient temperature are presented in Fig. 1 to 6 . The data for each chemical change was collected at each month but for convenience the initial, 2, 4, 6 and 8 months of storage have been considered for discussion. The results indicate that the moisture content of the osmotic dehydrated jackfruit increased in all treatments. This increase could be due to the higher relative humidity ( $85-95 \%$ in the rainy season) during the storage period of the products. The higher moisture content was observed in the osmotic dehydrated jackfruit prepared from $50^{0}$ Brix sugar syrup i.e. $\mathrm{T}_{4}(14.06 \%)$ followed by osmotic dehydrated jackfruit prepared from $45^{0}$ Brix sugar syrup i.e. $\mathrm{T}_{3}(13.36 \%)$ after a period of 8 months storage (Fig 1). Because of increase in moisture content of the osmotic dehydrated jackfruit the change in acidity is vary small (Fig. 2).

A remarkable reduction was noted in ascorbic acid (vitamin $C$ ) and $\beta$ carotene (vitamin A) contents of the samples during storage. The reduction could be due to both oxidative and non-oxidative changes as described by Eskin (1979) and Land (1962). Such changes altered the color of the product and lowered the 
flavor and nutritive value of the product. The maximum retention of vitamin $\mathrm{C}$ and $\beta$-carotene were observed in osmotic dehydrated jackfruit prepared from $50^{\circ}$ Brix sugar syrup i.e. $\mathrm{T}_{4}(3.56 \mathrm{mg} / 100 \mathrm{~g}$ and $53.02 \mu \mathrm{gm} / \mathrm{gm})$ followed by osmotic dehydrated jackfruit prepared from $45^{0}$ Brix sugar syrup i.e. $\mathrm{T}_{3}(3.54 \mathrm{mg} / 100 \mathrm{~g}$ and $48.56 \mu \mathrm{gm} / \mathrm{gm}$ ) after 8 months of storage (Fig. $3 \& 4$ ).
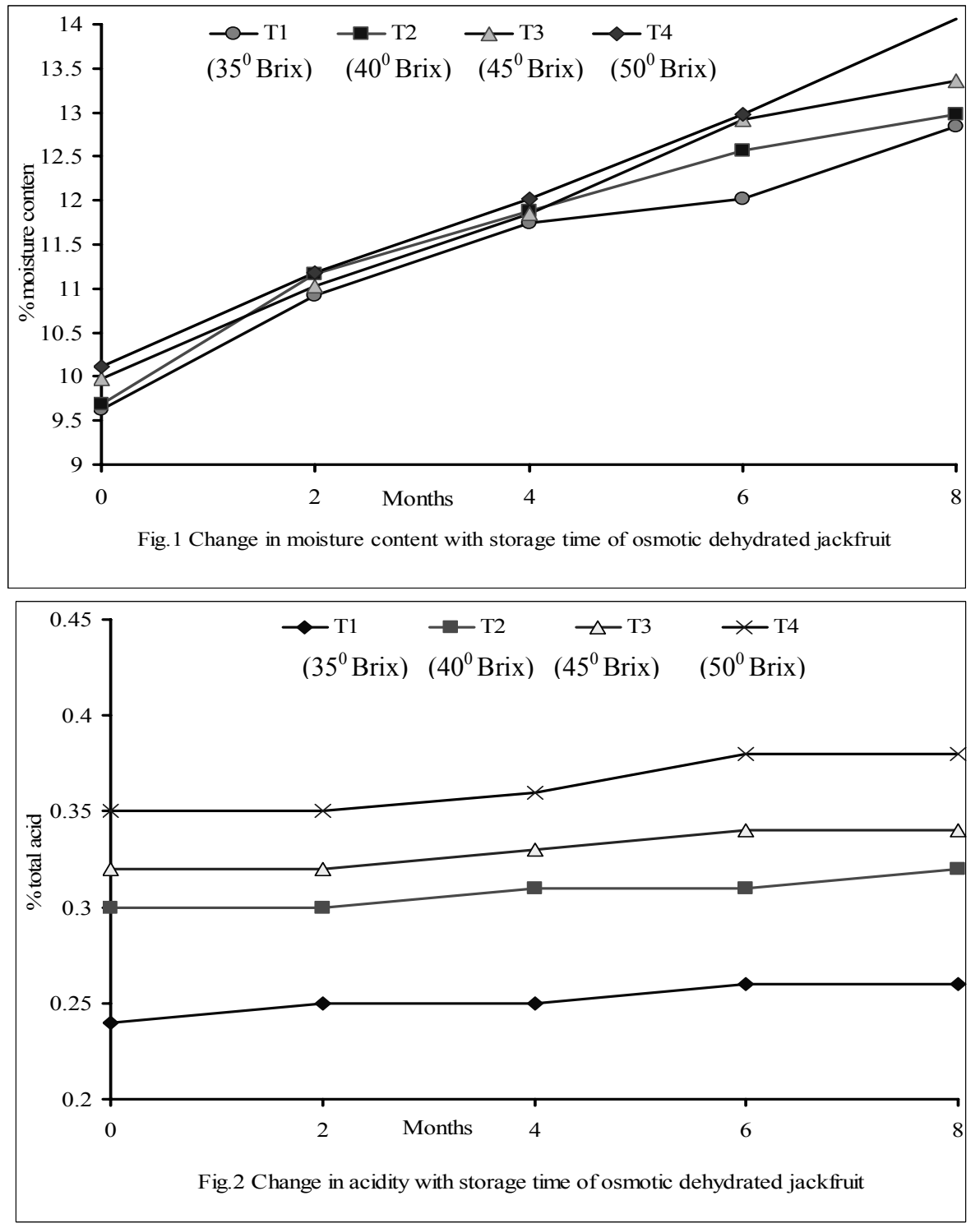

NB. $T_{1}=35^{\circ}$ Brix sugar syrup, $T_{2}=40^{\circ}$ Brix sugar syrup, $T_{3}=45^{\circ}$ Brix sugar syrup, $\mathrm{T}_{4}=50^{0}$ Brix sugar syrup 

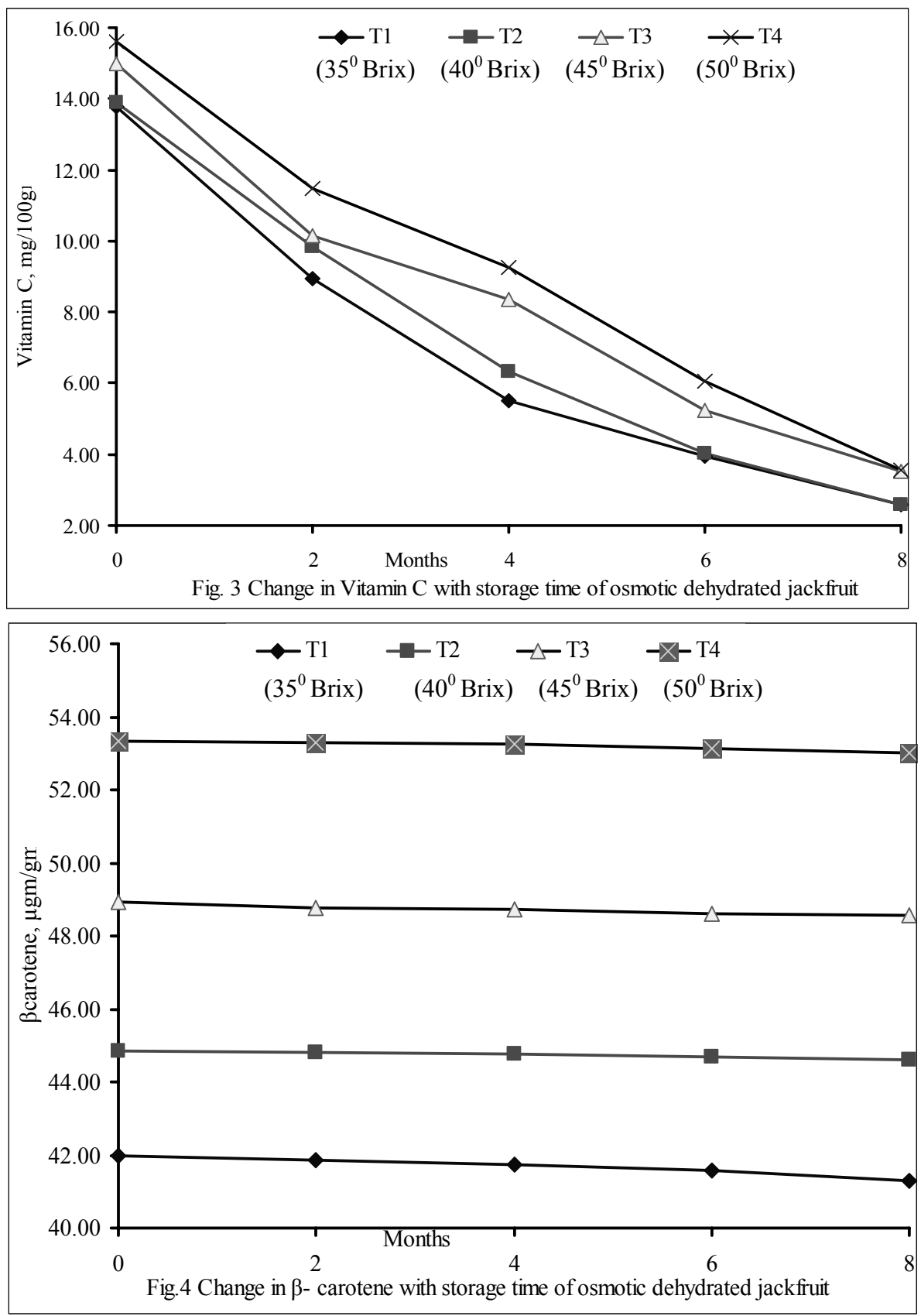

NB. $T_{1}=35^{\circ}$ Brix sugar syrup, $T_{2}=40^{\circ}$ Brix sugar syrup, $T_{3}=45^{\circ}$ Brix sugar syrup, $\mathrm{T}_{4}=50^{0}$ Brix sugar syrup 

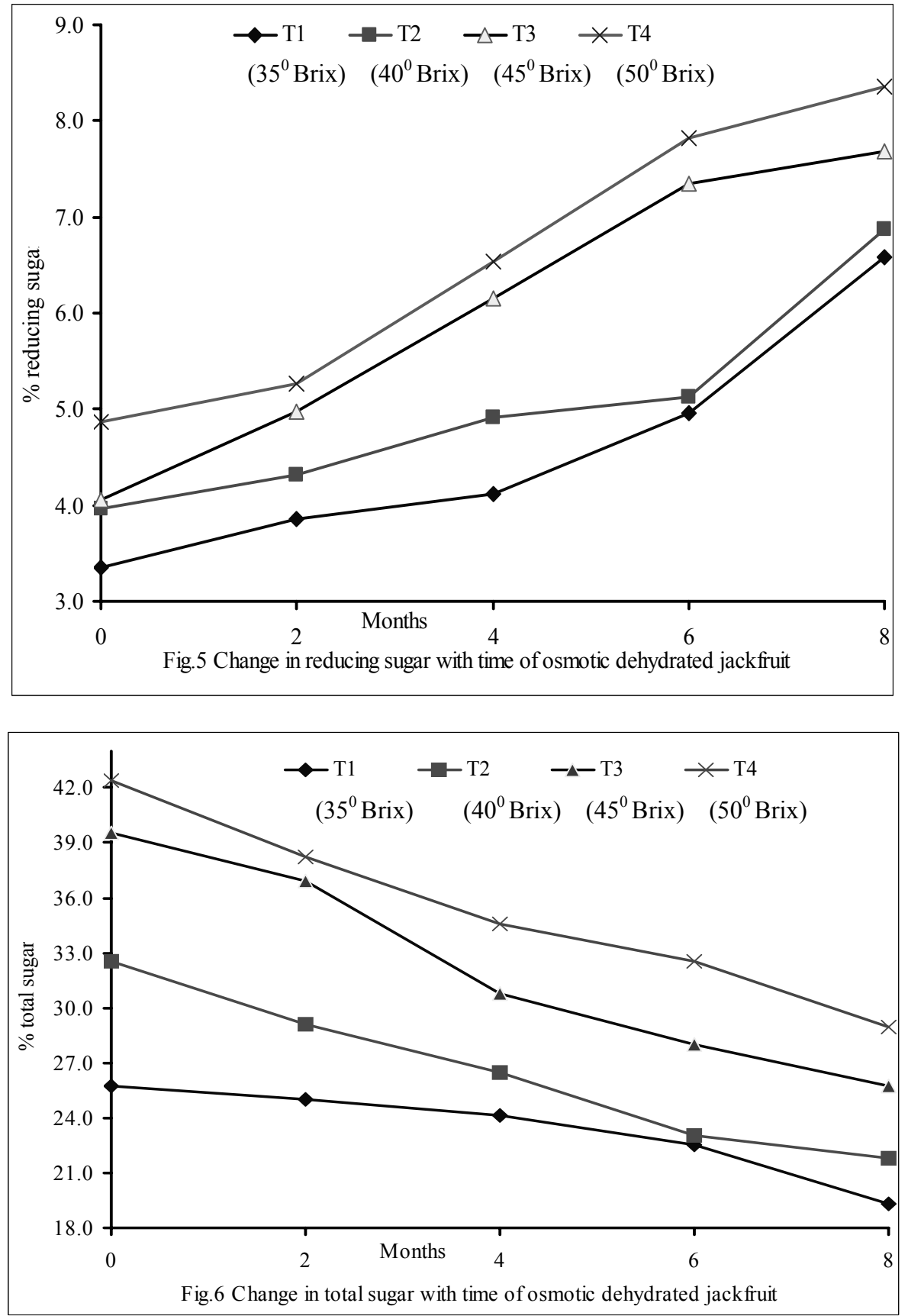

NB. $T_{1}=35^{0}$ Brix sugar syrup, $T_{2}=40^{0}$ Brix sugar syrup, $T_{3}=45^{0}$ Brix sugar syrup, $\mathrm{T}_{4}=50^{0}$ Brix sugar syrup 
The total sugar content was decreased and reducing sugar was increased in all the treatments of the osmotic dehydrated jackfruit after a storage period of 8 months (Fig. 5 \& 6). Decrease in total sugars in osmotic dehydrated jackfruit might be due to the significant increase in reducing sugars (Mir and Nath 1993) by acid hydrolysis of total and non-reducing sugars and thereby inversion of total (Rao and Roy 1980) and non-reducing sugars to reducing sugars (Meyer 1966; Roy and Singh 1979).

The bacteria, fungi, and yeast population enumerated during storage is presented in Table 1. The microbial counts of the osmotic dehydrated jackfruits of various sugar concentrations was nil initially and increased slightly during storage. No microorganism was traceable initially due to the higher dilution used for the enumeration. Osmotic dehydrated jackfruit prepared by $50^{\circ}$ brix sugar solution and $45^{\circ}$ brix sugar solution showed minimum of microbial counts than that prepared by $35^{\circ}$ and $40^{\circ}$ brix sugar solution during storage in high density polyethylene packet at ambient condition. Osmotic dehydrated jackfruit slices prepared by $35^{\circ}$ brix sugar solution exhibited slightly higher microbial population than the rest of the slices. In general, the microbial population of the jackfruit slices prepared for the experiment was quite low even at the end of 8 month of storage though there was a significant increase in moisture content over the period. The higher concentration of sugar in the syrup and the preservative (KMS) added, while preparing the jackfruit slices coupled with still low moisture content following storage (maximum 14\% m.c.), might have prevented the growth of microbes.

Table 1. Microbial population (CFU) of osmotic dehydrated jackfruit during storage.

\begin{tabular}{c|ccccccccccccc}
\hline $\begin{array}{c}\text { Storage } \\
\text { periods } \\
\text { (months) }\end{array}$ & \multicolumn{3}{c}{ Bacteria } & \multicolumn{3}{c|}{ Fungi } & \multicolumn{5}{c}{ Yeast } \\
\hline & $\mathrm{T}_{1}$ & $\mathrm{~T}_{2}$ & $\mathrm{~T}_{3}$ & $\mathrm{~T}_{4}$ & $\mathrm{~T}_{1}$ & $\mathrm{~T}_{2}$ & $\mathrm{~T}_{3}$ & $\mathrm{~T}_{4}$ & $\mathrm{~T}_{1}$ & $\mathrm{~T}_{2}$ & $\mathrm{~T}_{3}$ & $\mathrm{~T}_{4}$ \\
0 & 0 & 0 & 0 & 0 & 0 & 0 & 0 & 0 & 0 & 0 & 0 & 0 \\
2 & 2 & 2 & 1 & 1 & 2 & 1 & 1 & 1 & 1 & 1 & 1 & 1 \\
4 & 3 & 3 & 3 & 2 & 3 & 2 & 2 & 2 & 2 & 1 & 1 & 1 \\
6 & 3 & 2 & 2 & 2 & 3 & 2 & 2 & 2 & 2 & 1 & 1 & 1 \\
8 & 8 & 6 & 5 & 5 & 6 & 4 & 3 & 3 & 4 & 3 & 2 & 2 \\
\hline
\end{tabular}

The osmotic dehydrated jackfruit was organoleptically evaluated after every 2 months of storage period. But for the discussion, the 6 months and 8 months storage data have been taken. After 6 and 8 months of storage the highest overall 
acceptance score was obtained for treatment $T_{3}(7.7$ and 7.5$)$ followed by treatment $\mathrm{T}_{4}(6.9$ and 6.8$)$, respectively as shown in the Table 2 . It is noticed that nobody disliked the products even after 8 months of storage at ambient temperature.

\section{Table 2. Sensory scores of osmotic dehydrated jackfruit.}

\begin{tabular}{c|c|c|c|c|c|c|c|c}
\hline \multirow{2}{*}{$\begin{array}{c}\text { Treat- } \\
\text { ments }\end{array}$} & \multicolumn{3}{|c|}{$\begin{array}{c}\text { Sensory/organoleptic attributes after } 6 \\
\text { months of storage }\end{array}$} & \multicolumn{4}{|c}{$\begin{array}{c}\text { Sensory/organoleptic attributes after } 8 \\
\text { months of storage }\end{array}$} \\
\cline { 2 - 8 } & Color & $\begin{array}{c}\text { Taste/ } \\
\text { flavour }\end{array}$ & $\begin{array}{c}\text { Stickiness } \\
\text { /texture }\end{array}$ & $\begin{array}{c}\text { Overall } \\
\text { acceptability }\end{array}$ & Color & $\begin{array}{c}\text { Taste/ } \\
\text { flavour }\end{array}$ & $\begin{array}{c}\text { Stickiness/ } \\
\text { texture }\end{array}$ & $\begin{array}{c}\text { Overall } \\
\text { acceptability }\end{array}$ \\
\hline $\mathrm{T}_{1}$ & $8.2 \mathrm{a}$ & $5.7 \mathrm{c}$ & $4.7 \mathrm{c}$ & $5.4 \mathrm{~d}$ & $7.5 \mathrm{a}$ & $6.2 \mathrm{~d}$ & $5.3 \mathrm{~d}$ & $5.8 \mathrm{~d}$ \\
$\mathrm{~T}_{2}$ & $7.6 \mathrm{~b}$ & $5.8 \mathrm{c}$ & $5.3 \mathrm{~b}$ & $6.3 \mathrm{c}$ & $7.2 \mathrm{~b}$ & $6.4 \mathrm{c}$ & $6.1 \mathrm{c}$ & $6.1 \mathrm{c}$ \\
$\mathrm{T}_{3}$ & $7.3 \mathrm{~b}$ & $7.4 \mathrm{a}$ & $7.4 \mathrm{a}$ & $7.7 \mathrm{a}$ & $6.9 \mathrm{c}$ & $7.9 \mathrm{a}$ & $7.8 \mathrm{a}$ & $7.5 \mathrm{a}$ \\
$\mathrm{T}_{4}$ & $6.2 \mathrm{c}$ & $6.6 \mathrm{~b}$ & $7.6 \mathrm{a}$ & $6.9 \mathrm{~b}$ & $5.5 \mathrm{~d}$ & $7.2 \mathrm{~b}$ & $6.9 \mathrm{~b}$ & $6.8 \mathrm{~b}$ \\
$\mathrm{CV}$ & 2.26 & 2.6 & 3.36 & 3.03 & 1.48 & 1.44 & 1.77 & 1.53 \\
$(\%)$ & & & & & & & & \\
\hline
\end{tabular}

Mean scores having the same letter suffix do not differ significantly at 5\% (*) level of probability (DMRT)

Treatment: Hedonic scale indicating score:

$\mathrm{T}_{1}=35^{0}$ Brix sugar syrup $\quad 1=$ Dislike extremely, $\quad 2=$ Dislike very much,

$\mathrm{T}_{2}=40^{\circ}$ Brix sugar syrup $\quad 3=$ Dislike moderately, $\quad 4=$ Dislike slightly,

$\mathrm{T}_{3}=45^{\circ}$ Brix sugar syrup $\quad 5=$ Neither like nor dislike, $\quad 6=$ Like slightly,

$\mathrm{T}_{4}=50^{\circ}$ Brix sugar syrup $\quad 7=$ Like moderately, $\quad 8=$ Like very much, $9=$ Like extremely

So, we can conclude that considering the physico-chemical changes, overall acceptance of sensory evaluations and sugar quantity needed for the syrup, the treatment $\mathrm{T}_{3}$ i.e. $45^{0}$ Brix sugar syrup could be selected for commercial processing of osmotic dehydrated jackfruit.

\section{References}

Anonymous. 2011. Jackfruit - National Fruit of Bangladesh. http://www.bangladesh.com/ blog/jackfruit-national-fruit- of-bangladesh

BBS. 2007. Statistical Year Book of Bangladesh. Bangladesh Bureau of Statistics, Ministry of planning, Government of the People's Republic of Bangladesh.

Eskin, N.A.M. 1979. Plant pigments, flavours and textures. The Chemistry and Biochemistry of Selected Compounds. Academic Press, London.

Hossain, M. A. 2004. National case study on environmental requirement, market access/entry and export competitiveness of horticulture in Bangladesh. Paper presented in the national workshop on "Environmental Requirements and Market Access in the Horticulture Sector in Bangladesh" held in Dhaka during 4-5 October, 2004. 
Land, D.G. 1962. Stability of plant pigments. Advanced Food Research 2:50-56.

Mahadevan, A. and Sridhar R. 1982. Extraction and estimation of ascorbic acid methods. Physiological plant pathology. Sivakami Publishers, Madras, p-171.

Meyer, L.H. 1966. Food Chemisty, Reinhold Publishing Corporation, New York.

Mir, M.A. and Nath, N. 1993. Storage changes on fortified mango bars. J Food Sci. Technol. 30: 279-282.

Ranganna, S. (2007). Hand Book of Analysis and Quality Control for Fruits and Vegetables Products. Tata McGraw-Hill Publishing Company Limited, p-1099.

Rao, V.S and Roy, S.K. (1980). Studies on dehydration of mango pulp I. Standardization for making mango sheet/leather. Indian Food Packer 34: 64-71.

Roy, S.K. and Singh, R.N. (1979). Studies on utilization of bael fruit (Aegle marmelos) for processing: III. Preparation and preservation of bael fruit products. Indian Food Packer 33: 9-14

Tongsiri, N. and Alam, S. 2004. Promotion of agro-processing industry in Bangladesh: Potential constraints and policy issues. Bangladesh J. Political Economy 20 (1): 70-75. 